\title{
INNOVATION OF SUBSTITUTE MATERIAL TO CONSERVATION EFFORT OF Eusideroxylon zwageri ON WOODEN BRIDGE MAINTENANCE PROJECT
}

\author{
Ita Minarni ${ }^{1}$, Henry Wardhana ${ }^{2}$, Aqli Mursadin ${ }^{3}$, Mufidah Asyari ${ }^{4}$ \\ ${ }^{1}$ Postgraduated of Agricultural Doctoral Program, University of Lambung Mangkurat, Banjarbaru, \\ South Kalimantan, Indonesia (ULM) \\ ${ }^{2}$ Civil Engineering Program Study, Engineering Faculty, ULM \\ ${ }^{3}$ Mechanical Engineering Program Study, Engineering Faculty, ULM \\ ${ }^{4}$ Forestry Science Program Study, Forestry Faculty, ULM
}

\begin{abstract}
Infrastructure in the form of bridges is very important for Buntok Regency in Central Kalimantan where the area is swampy or lowland area. Total wood bridge construction is $45 \%$ from total 163 of all existing bridge types in this area those most of them are not proper condition considering some wood materials need to be replaced. The innovation has been developed to find the effective way how to maintenance the wooden bridge that has been idle for long time due to broken material on superstructure of the bridge. The floor of bridge that constructed with previous materials of ulin (Eusideroxylon zwageri) wooden bridge replaced by composite materials with floordeck concrete combination. The implementation of innovation on Tampa Bridge maintenance project showed better performance in terms of safety, comfortable and smoothness of bridge users from community around. In terms of budget aspect, the maintenance is cumulatively more efficient than if carrying out floor changes every year considering no longer possible to find ulin wood anymore. On technical point of view, with reinforced concrete can be applied to wooden bridges selectively only on ulin wooden bridges those the substructure is still intact and only minor damage to the spoorband and floor occurs. Bridge maintenance procedures need to be create to keep better maintenance for longer life time of the existing bridge that can be applied for another wooden bridge for maintenance.
\end{abstract}

Keyword. composite materials, important performance analysis, satisfaction level, ulin wooden bridge

Correspondent: ${ }^{1}$ itaminarni123@gmail.com;

2hendry.wardhana@ulm.ac.id;

3aqlimursadin@yahoo.com;

${ }^{4}$ mufie.ikhsan@ulm.ac.id 


\section{Introduction}

South Barito Regency is one of the area in Central Kalimantan Province, Indonesia with the capital city of Buntok are swampy or lowland area. Infrastructure in the form of bridges is very critical considering the area are swamp basin and river topography (Balasubramanian, 2017; PUPR Buntok, 2018). Cost of maintenance the bridges infrastructure mostly more expensive than other areas considering the bridges in the area is DD-2 category those $45.4 \%$ or 74 unit from total 163 bridges in this area were ulin (Eusideroxylon zwageri) wooden bridges with the condition 49 unit or $66.2 \%$ of the bridge were not in proper condition (Bajzecerová \& Kanócz, 2016; Lu \& Yang, 2017; PUPR Buntok, 2018).

Several types of damage on the superstructure of ulin wooden bridges is the material itself, including losses, broken, longitudinal or transverse cracks due to the influence of load effect and weather (PUPR Buntok, 2018; Ryall, 2001). The substructure and foundation of the ulin wooden bridge are relatively in good condition because consider they did not exposed to sunlight and rain or are protected from extreme weather changes so they are more durable (Kunarso et al., 2019; Modeer et al., 2016; PUPR Buntok. 2018).

An innovation was developed in 2018 to maintenance the ulin wooden bridge by protecting the floorboards of the bridge from the extreme weather and more load by coating it using a composite material of a combination of floordeck steel plate and reinforced concrete as a protective and a reinforcement layer. The results of the study carried out in terms of alternative treatments turned out to be effective and efficient in terms of budget and conservation effort of ulin wooden materials replacement. The costs of several alternative treatments show that the treatment with floordeck and reinforced concrete is the cheapest alternative compared to other design (PUPR Buntok, 2018)

\section{Materials and Methods \\ Research Stages}

To evaluate the results of innovation in maintaining the existing ulin wooden bridges by composites and reinforced concrete, the research is needed from two sides, namely from the performance of the bridge after three years of implementation and other side is the bridge user part. The evaluation of the performance of the bridge will be visually examined for signs of damage to the bridge structure, both the superstructure and the substructure (Miyamoto et al., 2001), so that it can be seen whether the innovations implemented in 2018 can be applied to other wooden bridges with a similar level of damage. Evaluation of satisfaction from bridge users as customers is focused on the results of the questionnaire submitted so that users' perceptions of the innovations that have been implemented are known. The results of the evaluation will be used as input for the formulation of strategies for improving bridge maintenance methods in the future ( $\mathrm{Lu} \&$ Yang, 2017)

\section{Bridge Condition and Performance Analysis}

The innovation developed on "Tampa" Bridge at Buntok Regency and the investigation is based on field observations of the bridge existing condition of the bridge which includes channels and water directions including riverbanks, embankments, and flood inundation areas, then the substructure of the bridge includes piers, fittings and sloof, and the superstructure of the bridge includes girders and floors. The process of inventorying the condition of the Tampa Bridge refers to the 2003 Bridge Management System (Gattulli \& Chiaramonte, 2005; Kepaptsoglou et al., 2006; Miyamoto et al., 2000). 


\section{Analysis of Bridge User Satisfaction Levels}

Using the Slovin formula with LHR population data of 36,000 Vehicles per year divided by 12 months and divided by 30 days in one month, the daily LHR population is 100 . Using the Slovin formula in equation (1), with a margin of error of $5 \%$, the number of samples is 80 samples as mention in formula 1 (Susanti et al., 2019).

$$
n=\frac{N}{1+N \cdot e^{2}} \quad \Rightarrow \quad n=\frac{100}{1+100.0,05^{2}} \quad \Rightarrow \quad n=80
$$

\section{Bridge Performance Analysis (Importance-Performance Analysis)}

Analyzing data from the results of the tabulation of research on the satisfaction level of bridge users to get the $\mathrm{Xi}$ and $\mathrm{Yi}$ coordinates of each of the variables studied. The average value of $\mathrm{Xi}$ and $\mathrm{Yi}$ is used as the cross of the Cartesian coordinate axes which divides into four quadrants, namely Quadrant A, Quadrant B, Quadrant C and Quadrant D (Ong \& Pambudi, 2014; Ormanovic \& Ciric, 2017)

\section{Result and Discussion}

\section{Design and Implementation of Innovation Analysis}

The replacement of ulin wooden by floordeck in concrete work is planned both in the preparation and execution process so that the casting is completed faster, very efficient in terms of installation. Using a steel floordeck to replace ulin wooden bridge floor can save cement, formwork, and scaffolding by up to $25-30 \%$ in material usage (Clouston \& Schreyer, 2008; Johnson, 2018). The construction design of the previous condition is shown in Figure 1, and design of the improvement innovation using a floordeck is as shown in Figure 2.

Figure 1. Overview of the Bridge Structure Before Innovation

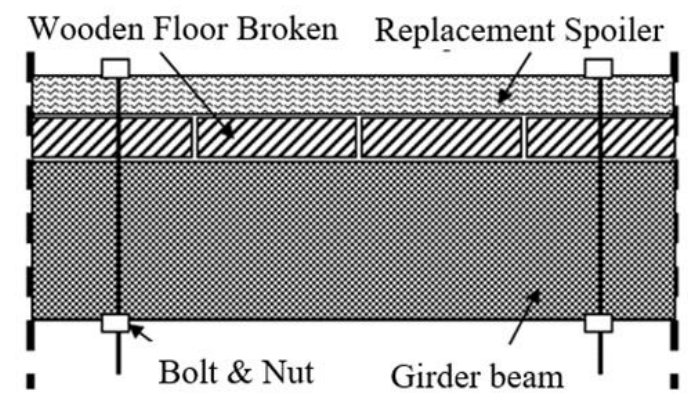

Figure 2. Innovative Design of Floordeck and Reinforced Concrete Installation

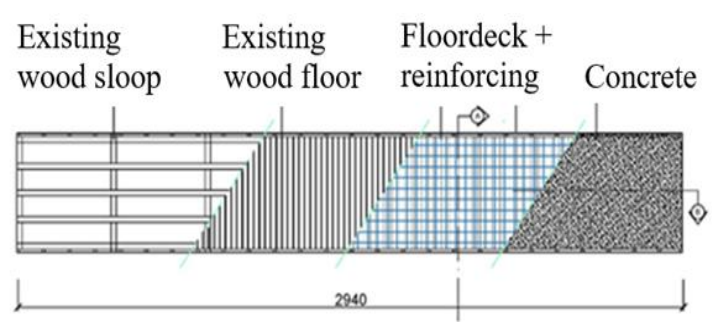

The Budget plan is prepared based on the calculation data of the volume of work obtained, the results of the calculation of the budget plan for the implementation of innovation work with a bridge size of $4 \times 29.4 \mathrm{~m}$ is cost of IDR 200,000,000 (two hundred million rupiah) or USD 13,350 including all costs. Some part of the implementation of innovation by floor deck as shown in Figure 3. (Dias et al., 2016; Sahab et al., 2005). 


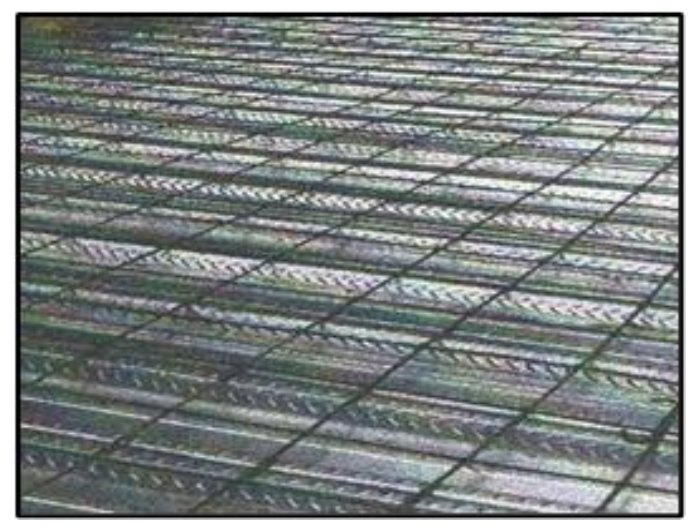

Figure 3. Installation of Reinforced Steel Composite and Floordeck

\section{Tampa Bridge Condition and Performance}

Planning and implementation analysis of the Tampa Bridge maintenance project was carried out based on the data obtained during the previous maintenance implementation. At the time of planning the maintenance of the bridge, there has been a change from the main material of ulin wooden bridge being replaced with a composite material of concrete and floordeck. The ulin wooden bridge, which had been broken for some time, could not be repaired (PUPR Buntok, 2018). In the end, the improvements could be made with the innovation of using floordeck composite materials and reinforced concrete then the Tampa Bridge can be used by the surrounding community as shown in Figure 4.
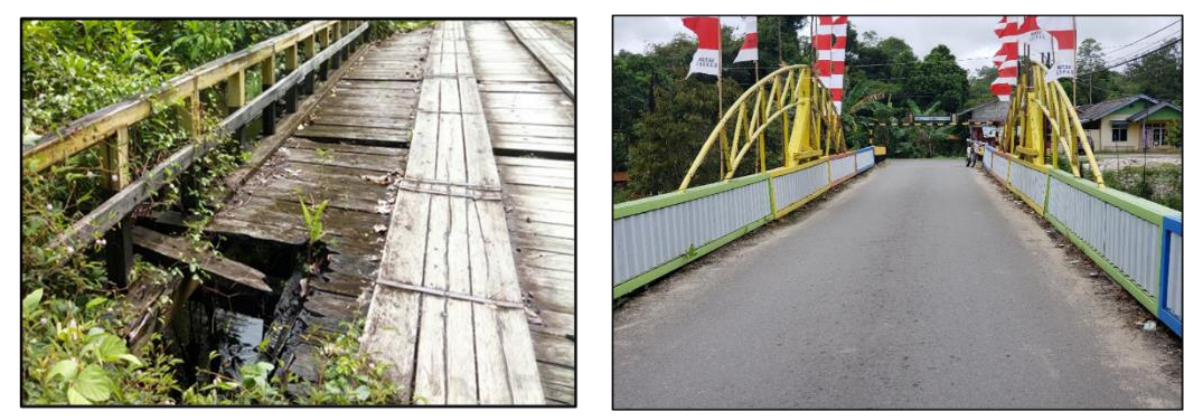

Figure 4. Bridge Condition Before and After Maintenance by Innovation

Investigation result of some technical data showed on safe level of self-load was $2,000.83$ ton that higher than soil strength base was $1,250.52$ ton. Noisy level was reduced $5.00 \mathrm{db}$ when the composite floor bridge was lower previous wooded floor bridge compare the previous one. Deflection test result of all spans average $1.01 \mathrm{~cm}$ lower than the standard mention of $1.33 \mathrm{~cm}$. The average concrete compressive strength result was 21.6 Mps higher than the standard 20.0 that the value can be accepted. Data of some technical investigation compare the previous wooden bridge by the innovation of composite of floordeck and concrete as mentioned in Table 1. 
Table 1. Data of Technical Result Investigation comparation previous condition and after implementing innovation on Tampa Bridge.

\begin{tabular}{lccc}
\hline \multicolumn{1}{c}{ Description } & Value & Result & Summary \\
\hline Up-structure Weight after Innnovation & 74.76 Ton & & \\
Soil Strength Base & $1,250.52$ Ton & self load $>1,250.52$ & Safe Level \\
Self Load & $2,000.83$ Ton & & \\
\hline Previous Wooden Floor Bridge & $60.00 \mathrm{db}$ & & \\
Composit Floor Bridge (After) & $55.00 \mathrm{db}$ & Noisy Level Lower & Accepted \\
Reduce Noisy Level (Comparation) & $5.00 \mathrm{db}$ & & \\
\hline Deflection Test of Span & $1.01 \mathrm{~cm}$ & Average $<1.33 \mathrm{~cm}$ & Accepted \\
Compressif Strength of Concrete & $21.6 \mathrm{Mps}$ & Average $>20.0 \mathrm{Mps}$ & Accepted \\
\hline
\end{tabular}

Investigation on Tampa Bridge is based on field observations of the existing condition of the bridge. Area to be investigation are channels and water directions including riverbanks, embankments, and flood inundation areas, then the bottom of the bridge includes piers, fittings and sloop (Gal \& Kryvoruk, 2010). For superstructure part includes the girders and floors, the results of investigation, the average importance the average service importance the results are presented in Table 2 and shown in Figure 5 and 6.

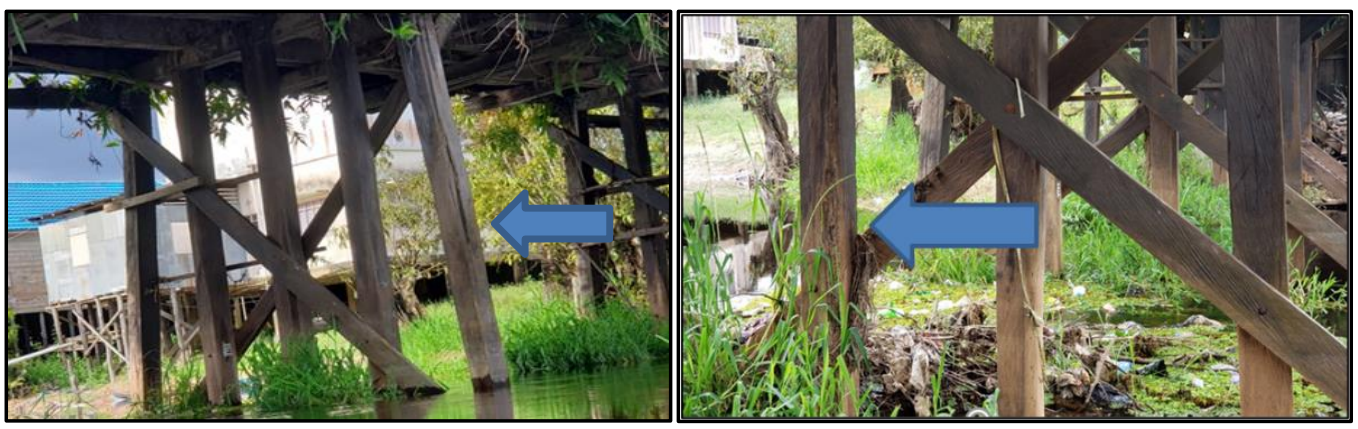

Figure 5. Tampa Bridge Condition during Investigation

Table 2. Calculation Result of Bridge Performance and User Satisfaction Analysis

\begin{tabular}{|c|c|c|c|c|c|c|c|}
\hline Indicator & Variable Indicator & $\begin{array}{l}\text { Average } \\
\text { (Yi) }\end{array}$ & $\mathrm{WF}(\%)$ & $\begin{array}{c}\text { Bridge Performance } \\
\text { Category }\end{array}$ & $\begin{array}{l}\text { Average } \\
\text { (Yi) }\end{array}$ & WS $(\%)$ & $\begin{array}{l}\text { Bridge User } \\
\text { Satisfaction }\end{array}$ \\
\hline $\mathrm{X} 1.1$ & Not slippery when it rains & 4.70 & 10.04 & Very Important & 4.61 & 46.28 & Very Good \\
\hline $\mathrm{X} 1.2$ & Fence installation & 4.68 & 10.00 & Very Important & 4.61 & 46.10 & Very Good \\
\hline $\mathrm{X} 1.3$ & Traffic sign & 4.71 & 10.06 & Very Important & 3.63 & 36.52 & Good \\
\hline $\mathrm{X} 2.1$ & Night lighting installation & 4.76 & 10.17 & Very Important & 3.59 & 36.51 & Good \\
\hline $\mathrm{X} 2.2$ & Spotlight on fence & 3.81 & 8.14 & Important & 3.81 & 31.01 & Good \\
\hline X3.1 & Bridge widht & 4.91 & 10.49 & Very Important & 3.91 & 41.02 & Good \\
\hline $\mathrm{X} 3.2$ & Cleanliness of bridge area & 4.90 & 10.47 & Very Important & 4.91 & 51.41 & Very Good \\
\hline $\mathrm{X} 4.1$ & No beggars in around area & 4.90 & 10.47 & Very Important & 4.90 & 51.30 & Very Good \\
\hline $\mathrm{X} 4.2$ & Load limit portal & 4.73 & 10.11 & Very Important & 4.54 & 45.90 & Very Good \\
\hline \multirow[t]{2}{*}{$\mathrm{X} 4.3$} & No hole on bridge floor & 4.70 & 10.04 & Very Important & 4.63 & 46.49 & Very Good \\
\hline & Total & 46.80 & & & WT & 432.54 & \\
\hline \multicolumn{2}{|c|}{ Customer Satisfaction Index (CSI) } & 86.51 & \multicolumn{5}{|c|}{ Category: Very Satisfy } \\
\hline
\end{tabular}

The summary of the investigation result shown in Figure 6, that the position of the data result in quadrant $\mathrm{A}$ means high priority to handle and some parts are in quadrant $\mathrm{B}$ means maintenance the existing those support better performance for the bridge itself and the user of the bridge. 
Quadrant A

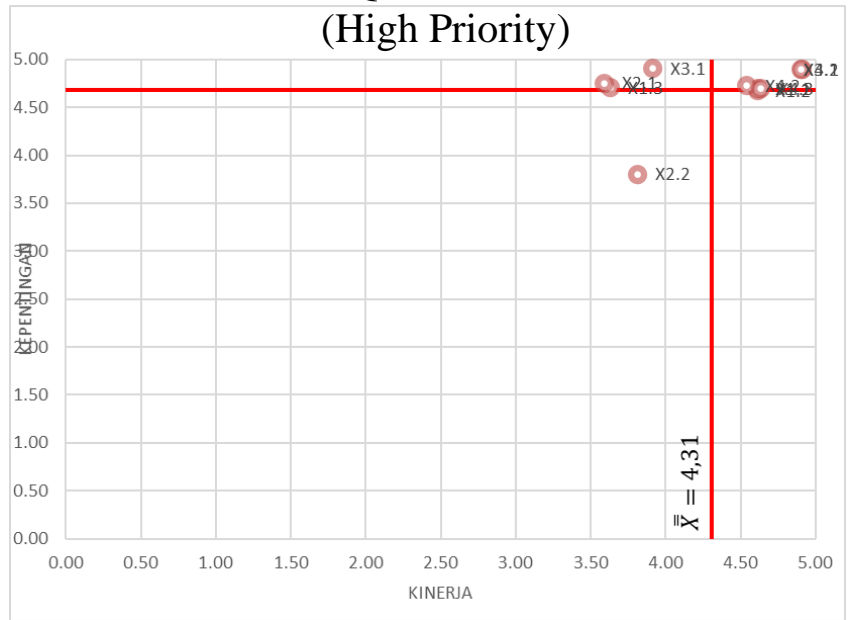

Quadrant B

(Maintenance)

Figure 6. Quadrant Summary Analysis of Bridge Performance and Users Satisfaction

The investigation carried out resulted in the implication that from a structural point of view, the implementation of the maintenance of ulin wooden bridge using reinforced concrete composites did not cause damage to the bridge structure. The increase in self-weight due to the floordeck and reinforced concrete does not result in a decrease in the bridge piers with a note that it is necessary to install a high barrier portal so that heavy-loaded transport no longer crosses the Tampa Bridge (Breyer et al., 2006; Emmerich et al., 2019; Miebach \& Niewerth, 2016).

The implementation of Tampa Bridge maintenance innovation has improved performance in terms of safety, comfortable and smoothness of Tampa Bridge users, especially from the sociological side from community around. In terms of budget aspect, the maintenance of the bridge with reinforced concrete composites is cumulatively more efficient than if carrying out floor changes every year because it is no longer possible to use ulin wooden bridge for new floors and ulin wood strictly prohibited to use new ulin wood anymore (Dias et al., 2016; Tazarv et al., 2019)

On technical point of view, the implementation of the maintenance of wooden bridge floors with reinforced concrete can be applied to wooden bridges selectively only on iron wood bridges whose substructure is still intact and only minor damage to the spoorband and floor occurs. Installation of the transport barrier portal is required to keep the bridge structure from overloading. Bridge maintenance procedures need to be made by the operator so that regular bridge cleaning can be scheduled from weeds (Ceccotti, 2002; Ryall, 2001; Zonta et al., 2007).

\section{Conclusions}

The innovation implemented on Tampa Bridge project showed better performance in terms of bridge performance and user of satisfaction. In terms of budget aspect, the maintenance is cumulatively more efficient. On technical point of view, the innovation can be applied to wooden bridges selectively. Bridge maintenance procedures need to be created to keep better maintenance for longer life time of the existing bridge.

\section{Acknowledgement}

Thanks for Mr. H. Eddy Raya Samsuri, ST, the Head Regency of Buntok, South Barito and all supported by Public Work Department Staff to compile and analysis the data, and fund supporting project to implement the innovation idea may applied to another wooden bridge at Buntok area. 


\section{References}

Bajzecerová, V., \& Kanócz, J. (2016). The Effect of Environment on Timber-concrete Composite Bridge Deck. Procedia Engineering. https://doi.org/10.1016/j.proeng.2016.08.264

Balasubramanian, A. (2017). Bridges and their types, Technical Report, Department of Earth Science, University of Mysore, India. In www.researchgate.net. https://doi.org/10.13140/RG.2.2.18109.46566

Breyer, D. E., Fridle, K. J., Cobeen, K. E., \& Pollock, D. G. (2006). Design of Wood Structures. In Design. Department of Civil Engineering, California State Polytechnic University, Ponoma, CA, USA: https://www.cabdirect.org/cabdirect/search/?q=pb\%3a\%22McGrawHill+Inc\%2.

Ceccotti, A. (2002). Composite concrete-timber structures. Progress in Structural Engineering and Materials. https://doi.org/10.1002/pse.126

Clouston, P., \& Schreyer, A. (2008). Design and Use of Wood-Concrete Composites. Practice Periodical on Structural Design and Construction. https://doi.org/10.1061/(asce)1084-0680(2008)13:4(167)

Dias, A., Skinner, J., Crews, K., \& Tannert, T. (2016). Timber-concrete-composites increasing the use of timber in construction. European Journal of Wood and Wood Products, 74(3), 443-451. https://doi.org/10.1007/s00107-015-0975-0

Emmerich, L., Wülfing, G., \& Brischke, C. (2019). The impact of anatomical characteristics on the structural integrity of wood. Forests, 10(2). https://doi.org/10.3390/f10020199

Gal, E., \& Kryvoruk, R. (2010). Properties of concrete. In Computational Modelling of Concrete Structures (pp. 137-144). https://doi.org/10.1201/b10546-17

Johnson, R. P. (2018). Composite Structures of Steel and Concrete. In Composite Structures of Steel and Concrete. https://doi.org/10.1002/9781119401353

Kepaptsoglou, K., Karlaftis, M. G., Bitsikas, T., Panetsos, P., \& Lambropoulos, S. (2006). A methodology and decision support system for scheduling inspections in a bridge network following a natural disaster. Proceedings of the $3 \mathrm{rd}$ International Conference on Bridge Maintenance, Safety and Management Bridge Maintenance, Safety, Management, Life-Cycle Performance and Cost. https://doi.org/10.1201/b18175-167

Kunarso, A., Yunardy, S., Harbi, J., Nugroho, D., Kamil, W., \& Haasler, B. (2019). Spatial Analysis to Identify the Priority Rehabilitation Area to Re-Introduce Ironwood (Eusideroxylon zwageri) in Meranti Sungai Merah Protected Forest, South Sumatra. IOP Conference Series: Earth and Environmental Science. https://doi.org/10.1088/1755-1315/298/1/012019

Lu, G., \& Yang, Y. J. (2017). Structural health monitoring. In Internet of Things and Data Analytics Handbook. https://doi.org/10.1002/9781119173601.ch40

Miebach, F., \& Niewerth, D. (2016). Latest developments in timber bridge constructions. WCTE 2016 - World Conference on Timber Engineering.

Miyamoto, A., Kawamura, K., \& Nakamura, H. (2001). Development of a bridge management system for existing bridges. Advances in Engineering Software. https://doi.org/10.1016/S0965-9978(01)00034-5

Miyamoto, Ayaho, Kawamura, K., \& Nakamura, H. (2000). Bridge management system and maintenance optimization for existing bridges. Computer-Aided Civil and Infrastructure Engineering. https://doi.org/10.1111/0885-9507.00170

Modeer, V., Bharil, R. K., \& Cooling, T. (2016). Bridge foundations. In Innovative Bridge Design Handbook: Construction, Rehabilitation and Maintenance. https://doi.org/10.1016/B978-0-12-800058-8.00023-2 
Ong, J. O., \& Pambudi, J. (2014). Analisis Kepuasan Pelanggan Dengan Importance Performance Analysis Di Sbu Laboratory Cibitung Pt Sucofindo (Persero). J@Ti Undip : Jurnal Teknik Industri, 9(1), 1-10. https://doi.org/10.12777/jati.9.1.1-10

Ormanovic, S., \& Ciric, A. (2017). Importance-Performance Analysis: Different Approaches (December).

PUPR Buntok. (2018). Bridge Inventory Result Database of South Barito Regency, Central Kalimantan. Department of Public Work of South Barito Regency Annual Report.

Ryall, M. (2001). Inspection and condition rating. In Bridge Management. https://doi.org/10.1016/b978-075065077-9/50003-4

Sahab, M. G., Ashour, A. F., \& Toropov, V. V. (2005). Cost optimisation of reinforced concrete flat slab buildings. Engineering Structures. https://doi.org/10.1016/j.engstruct.2004.10.002

Susanti, A., Soemitro, R. A. A., Suprayitno, H., \& Ratnasari, V. (2019). Searching the Appropriate Minimum Sample Size Calculation Method for Commuter Train Passenger Travel Behavior Survey. Journal of Infrastructure \& Facility Asset Management, 1(1), 47-60. https://doi.org/10.12962/jifam.v1i1.5232

Tazarv, M., Carnahan, Z., \& Wehbe, N. (2019). Glulam timber bridges for local roads. Engineering Structures. https://doi.org/10.1016/j.engstruct.2019.03.012

Zonta, D., Zandonini, R., \& Bortot, F. (2007). A reliability-based bridge management concept. Structure and Infrastructure Engineering. https://doi.org/10.1080/15732470500315740 